\title{
Influence of density of saccharose and aucsins upon the process of formation of tubers of potato in crop of stolons in vitro
}

\author{
H. Balashova, \\ doctor of agricultural sciences \\ Yu. Lavrynenko, \\ Corresponding Member of NAAS, \\ doctor of agricultural sciences \\ B. Kotov \\ Institute of irrigated agriculture NAAS
}

The purpose. To determine the optimum technological methods influencing heightening intensity of tuber-formation of potato of early ripening variety Kobza in crop of stolons in vitro. Methods. Complex use of laboratory, mathematical-statistical, calculation-comparative methods and system analysis. Results. Experimental data are resulted on influence of density of saccharose and aucsins in nutrient medium on induction of tuber-formation at reproduction of potato in crop of stolons in vitro. Conclusions. The maximum productivity and reward payment of holdings at determination of optimum elements of technique of growing of microtubers of early ripening variety of potato Kobza in crop of stolons in vitro is generated at adding in nutrient medium of saccharose in dose of $80 \mathrm{~g} / \mathrm{l}$ and kinetin in dose of $0,5 \mathrm{mg} / \mathrm{l}$. Mass of average microtuber is $53,2 \mathrm{mg}$, amount of stolons which have organized microtubers $-87 \%$ at the cost price of microtuber $2,49 \mathrm{hrn}$ and profitableness of production $141 \%$.

Key words: crop of stolons in vitro, tuber-formation, amount of stolons, height of plants, saccharose, kinetin, nutrient medium, mass of microtubers.

Biotechnologies are widely developing in various directions, effective measures have been developed to combat against viral diseases in the seed production of potatoes [1-4]. The methods of potato recovery using meristem culture, productive methods of cultivation and clonal micropropagation of plants, highly sensitive immunological [5-7] and PCR methods for the diagnosis of viruses were recommended. The search for ways to create virus-like varieties using genetic engineering [8], cellular and tissue technologies [9-12].

The process of tuber formation in vitro can be regulated by a number of endo-and exogenous factors (excess of assimilants, hormonal status of plants, temperature regime, photoperiod, light intensity, $\mathrm{pH}$ and culture medium composition), which is the basis for obtaining high-quality material in the primary seed production of potato. It significantly improves plant growth in vitro by adding growth regulators to the culture medium. These include auxins, cytokinins, gibberellins, abscisic acid, ethylene. Of particular importance for the cultivation of plants in vitro are the first three groups of substances.

The group of cytokinins includes adenine, kinetin, BAP, zeatin, etc. Synthesis of cytokinins in plants occurs mainly in the roots. An increase in the intensity of tuber formation in the cultivation of plants on a culture medium with a content of cytokinins in particular kinetin has been established, which activates the incorporation of amino acids into the polypeptide chain, and this results in more intensive protein biosynthesis and enhanced cell division. Of particular importance in this case is the concentration of phytohormone in the culture medium [13]. From the concentration and the ratio of biologically active substances in the plant depends the beginning and intensity of stolono- and tuber formation. The same pattern is also characteristic of biologically active substances used by plants from the culture medium. 
For the best development of plants in vitro, sucrose should be used as a source of carbohydrate nutrition in the culture medium. The concentration of sucrose is a factor of stolon- and tuber formation and accumulation of microtuber mass.

Research objective: Study of the influence of the concentration of sucrose and phytohormones on potato tuber process of the early-ripening variety of potatoes Kobza in culture in vitro stolons to increase the amount of production of the original healthy planting stock.

Materials and methods of research. In the conditions of a microclonal laboratory, we conducted an experiment in which two factors were put to study: factor $A$ - sucrose concentration (6, 8 and $16 \%)$, factor $B$ - kinetin content $(0.5,1.0$ and $2.5 \mathrm{mg} / \mathrm{L})$.

On the 20th day of cultivation, from the cuttings of plants in vitro, potato sort Kobza, which were grown on a culture medium Murashige, Skoog (MS) with a sugar content of $6 \%$ and kinetin $0.5 \mathrm{mg} / \mathrm{L}$, were removed stolons and transplanted on to a culture medium which consists of sugar 6,8 and $16 \%$ and kinetin $-0.5 ; 1.0$ and $2.5 \mathrm{mg} / \mathrm{L}$. Cultivation of microtubers was carried out at a temperature of $20-22^{\circ} \mathrm{C}$ in diffuse illumination.

The studies were performed according to generally accepted methodologies. In order to obtain the initial potato plants that were improved by the biotechnological method in vitro, a thermo-chemotherapy method was used in combination with the culture of the apical meristems according to the "Methodological recommendations for conducting studies with potatoes" [14], the methodological recommendations "Improvement of potatoes in in vitro culture" [15], "Optimizing the methods of healing, multiplying and protecting potato seeds from a viral infection" [16] and "Biotechnological methods for obtaining and evaluating potato recovery" [17]. The experiments were carried out according to standard methods [18]. The economic efficiency of production of a healthy source material in an in vitro culture was calculated based on the actual cost of microtubers according to the technological maps.

Research results. Observations show that the content of sucrose and kinetin significantly influenced the height of the plants. So, already on the 20th day after the transplantation, at a content of 60 and 80 $\mathrm{g} / \mathrm{L}$ of sucrose, the plant height, on average by factor, was $3.2 ; 2.7 \mathrm{~cm}$, while using $160 \mathrm{~g} / \mathrm{L}$, only $0.8 \mathrm{~cm}$. The number of stolons that formed the microtuber was higher when using $80 \mathrm{~g} / \mathrm{L}$ of sucrose and amounted, on average by factor, to $35.6 \%$, which exceeded other variants by 12.4 and $11.2 \%$ (Table 1 ). At the same time, a large number of stolons that formed sprout were formed with application of $60 \mathrm{~g} / \mathrm{L}$ sucrose and on average exceeded other variants by 11.1 and $43.3 \%$.

On the 40th day of cultivation, the situation with plant height remained unchanged. At the same time, the number of stolons that formed the microtubers increased at a sucrose concentration of $60 \mathrm{~g} / \mathrm{L}$ and amounted on average by factor of $57.8 \%$, exceeding the other experiment variants by 8.9 and $6.7 \%$.

1. Effect of concentration sucrose and phytohormones on potato tuber process in culture in vitro stolons of early-ripening potato sort Kobza

\begin{tabular}{|c|c|c|c|c|c|c|c|c|c|}
\hline \multirow{3}{*}{ 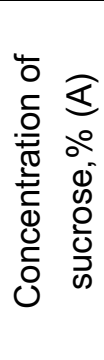 } & \multirow{3}{*}{ 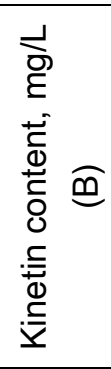 } & \multicolumn{5}{|c|}{ The indicators of plant growth and development per day, } & \multirow{3}{*}{ 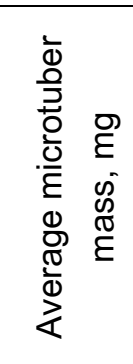 } & \multirow{3}{*}{ 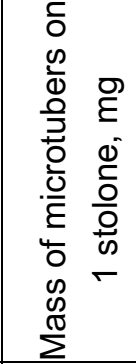 } & \multirow{3}{*}{ 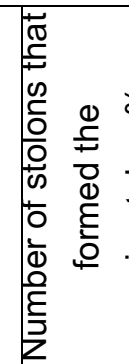 } \\
\hline & & \multicolumn{3}{|c|}{ 20th } & \multicolumn{2}{|r|}{ 40th } & & & \\
\hline & & 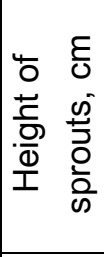 & 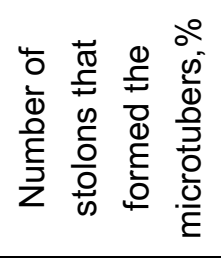 & 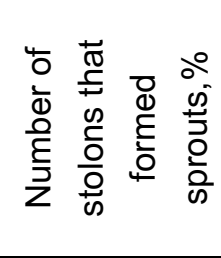 & 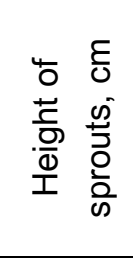 & 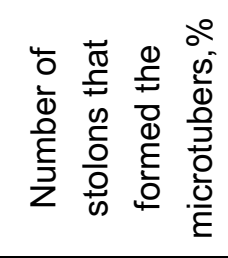 & & & \\
\hline \multirow{3}{*}{6} & 0,5 & 3,6 & 23,0 & 86,6 & 3,7 & 73,3 & 48,8 & 42,1 & 80 \\
\hline & 1,0 & 3,2 & 26,7 & 66,7 & 3,3 & 53,3 & 41,5 & 24,9 & 60 \\
\hline & 2,5 & 2,9 & 20,0 & 70,0 & 2,9 & 46,7 & 51,3 & 25,7 & 50 \\
\hline \multirow{3}{*}{8} & 0,5 & 1,6 & 46,7 & 56,7 & 2,5 & 56,7 & 53,2 & 42,5 & 87 \\
\hline & 1,0 & 3,3 & 33,3 & 73,3 & 4,2 & 46,7 & 61,0 & \begin{tabular}{|l}
42,7 \\
\end{tabular} & 70 \\
\hline & 2,5 & 3,1 & 26,7 & 60,0 & 3,2 & 43,3 & 49,2 & 32,8 & 60 \\
\hline
\end{tabular}




\begin{tabular}{|c|c|c|c|c|c|c|c|c|c|}
\hline \multirow{3}{*}{16} & 0,5 & 0,95 & 13,3 & 40,0 & 1,2 & 50,0 & 48,8 & 29,3 & 60 \\
\hline & 1,0 & 0,9 & 36,7 & 30,0 & 0,9 & 60,0 & 31,1 & 19,7 & 63 \\
\hline & 2,5 & 0,45 & 23,3 & 23,3 & 0,6 & 43,3 & 35,2 & 17,6 & 50 \\
\hline \multicolumn{7}{|c|}{ Multiple correlation index (R) } & 0,623 & 0,761 & $\begin{array}{l}0,81 \\
3\end{array}$ \\
\hline \multirow{2}{*}{\multicolumn{2}{|c|}{ LSD $_{05}$}} & & & & & & 4,8 & 4,2 & \\
\hline & & & & & & & 5,9 & 5,3 & \\
\hline
\end{tabular}

By the amount of kinetin it should be noted that this factor also influenced the indicators of the accumulation of productivity by plants. So, on the 20th day of cultivation with application of $1.0 \mathrm{mg} / \mathrm{L}$ kinetin the plant height, on average by factor, was higher in comparison with the concentration of 0.5 and $2.5 \mathrm{mg} / \mathrm{L}$ by 13.6 and $19.0 \%$, according. At the concentration of kinetin in the nutrient solution of $1.0 \mathrm{mg} / \mathrm{L}$, the number of stolons that formed the microtuber was high and amounted to $32.2 \%$ on average, which exceeded the other variants by 4.5 and $8.9 \%$. The number of stolons that formed sprouts depending on the concentration of kinetin $0.5 ; 1.0$ and $2.5 \mathrm{mg} / \mathrm{L}$ was accordingly $61.1 ; 56.7$ and $51.1 \%$.

On the 40th day of cultivation, the plant height, depending on the kinetin content in the culture medium, remained unchanged, but the number of sprouts that formed the microtuber was high, at a kinetin concentration of $0.5 \mathrm{mg} / \mathrm{L}$ by 6.7 and $15.6 \%$.

At the end of vegetation, the average correlation of the mass of microtubers $(R=0.623)$ and the strong one for microtubers per 1 stolon $(R=0.761)$ and the number of stolons that formed the microtuber $(R=0.813)$ from the interaction of the factors that were studied (Table 2$)$.

1. Coefficients $(r)$ of the correlation of economic efficiency and productivity in culture in vitro stolons early ripening sort of potato Kobza on the concentration of sucrose and phytohormones

\begin{tabular}{|l|l|l|}
\hline Index & $\begin{array}{l}\text { Concentration } \\
\text { sucrose, \%, } \\
\text { factor } \mathrm{A}\end{array}$ & $\begin{array}{l}\text { Content of kinetin, } \\
\mathrm{mg} / \mathrm{L}, \\
\text { factor B }\end{array}$ \\
\hline Average microtuber mass, $\mathrm{mg}$ & $-0,597 \pm 0,138$ & $-0,178 \pm 0,169$ \\
\hline Mass of microtubers on 1 stolone, mg & $-0,576 \pm 0,140$ & $-0,498 \pm 0,149$ \\
\hline Number of stolons that formed the microtubers, \% & $-0,339 \pm 0,161$ & $-0,738 \pm 0,116$ \\
\hline Prime coast, UAH/microtuber & $0,606 \pm 0,136$ & $0,702 \pm 0,122$ \\
\hline Rentability, \% & $-0,564 \pm 0,142$ & $-0,677 \pm 0,126$ \\
\hline
\end{tabular}

On average by factor, the mass of the average microtuber was the highest with 60 and $80 \mathrm{~g} / \mathrm{L}$ sucrose and amounted to 47.2 and $54.5 \mathrm{mg}$, which exceeded the variants using a concentration of $160 \mathrm{~g} / \mathrm{L}$ at 22.9 and $41.9 \%$, according. The mass of microtubers per 1 stolon was the highest $(39.3 \mathrm{mg})$ with $80 \mathrm{~g} / \mathrm{L}$ sucrose, which is higher than in other variants by 8.4 and $17.1 \mathrm{mg}$. It should be noted the average reverse pairing relationship between the concentration of sucrose in the culture medium and the productivity of plants, that is, with an increase in the content of sucrose, the weight of the average microtuber decreases $(r=-0.597+0.138)$, the mass of the microtuber per stolon $(r=-0.576+0.140)$ and number of stolons that formed the microtubers $(r=-0.339+0.161)$.

Regarding the content of phytohormone in the culture medium, it should be noted that the concentration of kinetin also influences the formation of plant productivity in culture in vitro stolons of the early-ripening sort of potato Kobza. In particular, strong feedback was found between the concentration of kinetin and the number of stolons that formed microtubers $(r=-0.738+0.116)$. With the decrease in the kinetin content to $0.5 \mathrm{mg} / \mathrm{L}$ in the culture medium, their amount increases by 11.4 and $22.4 \%$, compared to a concentration of 1.0 and $2.5 \mathrm{mg} / \mathrm{L}$, respectively. Somewhat less influence is exerted by kinetin on mass formation of microtubers on one stolon $(r=-0.498+0.148)$, it was greater with $0.5 \mathrm{mg} / \mathrm{L}$ of kinetin 
and exceeded other variants by 8.9 and $12.6 \mathrm{mg}$. The concentration of kinetin in the culture medium had practically no effect on the accumulation of mass of microtubers $(r=-0.178+0.169)$.

By the end of the growing season, the maximum number of stolons that the microtubers formed was, on average, by factors, with $80 \mathrm{~g} / \mathrm{L}$ of sucrose and $0.5 \mathrm{mg} / \mathrm{L}$ of kinetin (Figure 1).

Regression analysis of the obtained data made it possible to obtain linear mathematical models of the dependence of the productivity of potato plants of the early sort Kobza variety in culture in vitro stolons on the sucrose concentration and kinetin content in the culture medium (Table 3).

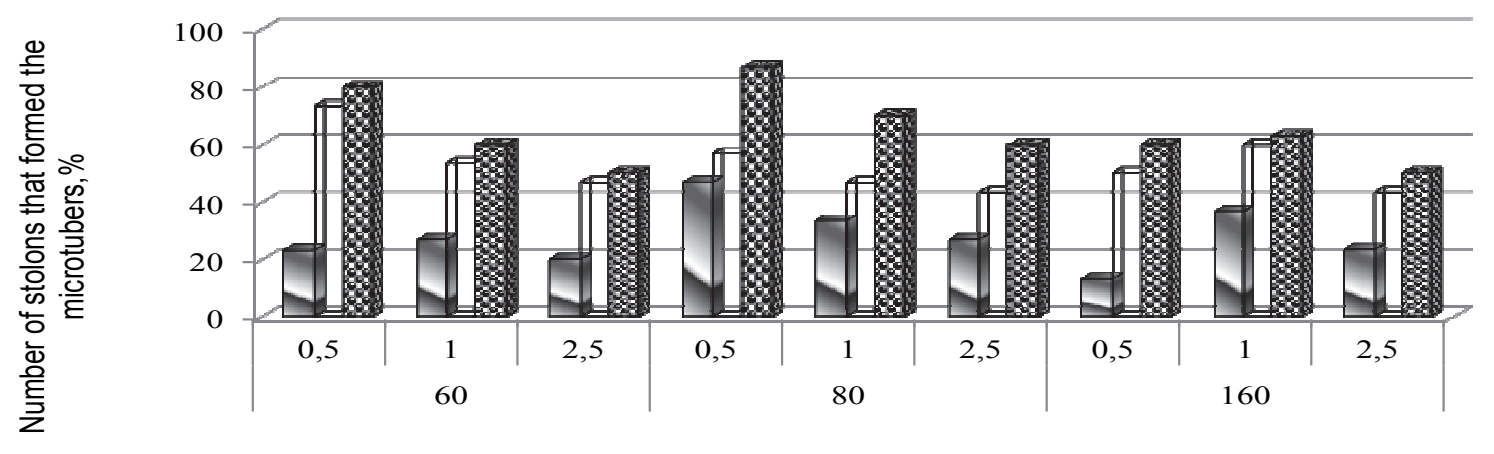

Kinetin content, mg/L

Sucrose concentration, g/L

$\Xi_{20 \text { th day }} \square_{40 \text { th day }}$ harvesting

Fig. 1. Potato tuber process in culture in vitro stolons of the early ripening sort of potato Kobza depending on the concentration of sucrose and the content of kinetin in a culture medium

1. The regression equation for the dependence of potato tuber process in culture in vitro stolons of the early ripening sort of potato Kobza on the concentration of sucrose $\left(X_{1}\right)$ and the content of kinetin in the culture medium $\left(\mathrm{X}_{2}\right)$

\begin{tabular}{|l|l|}
\hline Index & Form of equation \\
\hline Average microtuber mass, $\mathrm{mg}$ & $Y=61,17-1,21 X_{1}-1,83 X_{2}$ \\
\hline Mass of microtubers on stolone, $\mathrm{mg}$ & $Y=50,37-1,23 X_{1}-5,42 X_{2}$ \\
\hline Number of stolons that formed the microtubers, \% & $Y=87,44-0,93 X_{1}-10,28 X_{2}$ \\
\hline
\end{tabular}

Calculations of the economic efficiency of cultivation of microtubers of the early sort of potato Kobza in culture in vitro stolons, depending on the factors studied, showed that the cost of one microtuber, on average by factor, when using a culture medium containing $8 \%$ sucrose by 10.2 and $30.3 \%$ lower, than at 6 and $16 \%$, respectively; With a kinetin content of $0.5 \mathrm{mg} / \mathrm{L} \mathrm{-} \mathrm{by} 13.2$ and $32.2 \%$ lower than when using 1.0 and $2.5 \mathrm{mg} / \mathrm{L}$, respectively (Table 4). The same dependence was also noted in terms of profitability. 
2. Economic efficiency of cultivation of microtubers of early-ripening sort of potato Kobza in culture in vitro stolons depending on sucrose concentration and kinetin content in culture medium

\begin{tabular}{|c|c|c|c|c|c|c|}
\hline $\begin{array}{c}\text { Sucrose } \\
\text { concentration, } \\
\% \text { (A) }\end{array}$ & $\begin{array}{l}\text { Kinetin } \\
\text { content, } \\
\text { mg/L (B) }\end{array}$ & 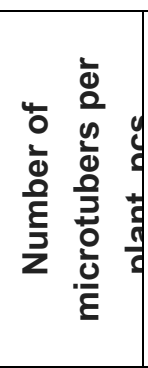 & 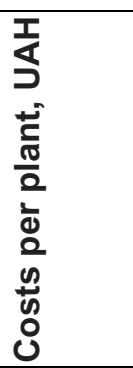 & 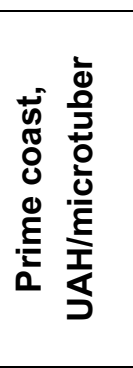 & 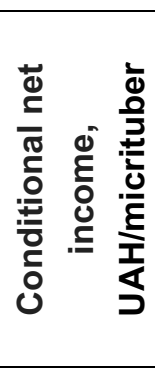 & 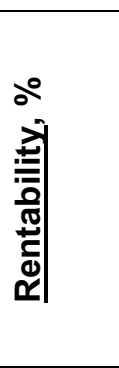 \\
\hline \multirow{3}{*}{6} & 0,5 & 0,80 & 2,08 & 2,60 & 3,40 & 131 \\
\hline & 1,0 & 0,60 & 2,11 & 3,52 & 2,48 & 71 \\
\hline & 2,5 & 0,50 & 2,24 & 4,48 & 1,52 & 34 \\
\hline \multirow{3}{*}{8} & 0,5 & 0,87 & 2,17 & 2,49 & 3,51 & 141 \\
\hline & 1,0 & 0,70 & 2,20 & 3,14 & 2,86 & 91 \\
\hline & 2,5 & 0,60 & 2,32 & 3,87 & 2,13 & 55 \\
\hline \multirow{3}{*}{16} & 0,5 & 0,60 & 2,53 & 4,22 & 1,78 & 42 \\
\hline & 1,0 & 0,63 & 2,56 & 4,06 & 1,94 & 48 \\
\hline & 2,5 & 0,50 & 2,68 & 5,36 & 0,64 & 12 \\
\hline
\end{tabular}

\section{Conclusions}

Maximum productivity and efficiency of investment in determining the optimal cell technology growing microtubers early maturing varieties of potatoes in the culture Kobza stolons formed in vitro when added to the culture medium of $80 \mathrm{~g} / \mathrm{L}$ of sucrose and $0.5 \mathrm{mg} / \mathrm{L}$ of kinetin: average weight of microtubers - 53.2 $\mathrm{mg}$, the number of stolons, microtubers formed $\mathrm{a}-87.0 \%$ at a cost of microtubers $-2.49 \mathrm{UAH}$ and rentability $141 \%$.

\section{Bibliography}

1. Vnedrenie sistemy semenovodstva kartofelja na ozdorovlennoj osnove v Respublike Tatarstan / F. F. Zamalieva, G. F. Safiullina, R. R. Nazmieva [i dr.] // Kartofelevodstvo v regionah Rossii : aktual'nye problemy nauki i praktiki / VNIIKH. - M., 2006. - S. 167-181.

2. Semenovodstvo - na ozdorovlennuju meristemnuju osnovu / A. S. Zajnulina [i dr.] // Kartofel' i ovoshhi. - 2001. - №1. - S. 9-10.

R. G. Gareev, F. F. Zamalieva,

3. Optimizacija priemov ozdorovlenija, razmnozhenija i zashhity semennogo kartofelja ot virusnoj infekcii : metod. ukazanija / BelNIIZR. - Minsk, 1996. - 16 s.Almasi A. Photosintetic aleration of virus infected plants / A. Almasi, A. Harsanyi, R. Gaborjanyi // Acta Phytopathol Acad. - 2001. - Vol. 36. - N $1 / 2 .-$ P. $15-29$.

4. Vozmozhnosti ispol'zovanija immunohromatograficheskih test-sistem dlja diagnostiki virusov kartofelja / D. V. Kravchenko, A. I. Uskov, Ju. A. Varicev [i dr.] // Kartofelevodstvo : sb. nauch. tr. : materialy koordinac. soveshh. i nauch.-prakt. konf., posvjashh. 120-letiju so dnja rozhdenija A. G. Lorha / RASHN, VNIIKH ; pod red. E. A. Simakova. - M., 2009. - S. 208-213.

5. Sovershenstvovanie virusologicheskogo kontrolja $v$ processe formirovanija i podderzhanija banka zdorovyh sortov kartofelja / B. V. Anisimov, E. V. Ovjes, O. V. Topisheva [i dr.] // Kartofelevodstvo : sb. nauch. tr. : materialy koordinac. soveshh. i nauch.-prakt. konf., posvjashh. 120-letiju so dnja rozhdenija A. G. Lorha / RASHN, VNIIKH ; pod red. E. A. Simakova. - M., 2009. - S. 188-192.

6. Sologub A.S. Sposob biohimicheskoj identifikacii sortov kartofelja / A. S. Sologub, P. A. Mel'nik // Kartofelevodstvo : sb. nauch. tr. : materialy koordinac. soveshh. i nauch.-prakt. konf., posvjashh. 120-letiju so dnja rozhdenija A. G. Lorha / RASHN, VNIIKH ; pod red. E. A. Simakova. - M., 2009. - S. 178-182. 
7. Agrobakterial'naja transformacija sortov kartofelja ukrainskoj selekcii SRY-genami, obespechivajushhimi ustojchivost' k nasekomym- vrediteljam / V. N. Zhuk, T. N. Olijnyk, A. I. Emec [i dr.] // Kartofelevodstvo : sb. nauch. tr. - Minsk, 2008. - T. 14. - S. 67-73.

8. Hal R. Biotehnologija s.-h. rastenij / R. Hal ; per. s angl. - M. : Agropromizdat, 1998. $-498 \mathrm{~s}$.

9. Awan A.R. In vitro elimination of potato leaf roll polerovirus from potato varieties / A. R. Awan, S. M. Mughal // European Journal of Scientific Research. - 2007. - Vol. 18. - N1. - P. 155-164.

10. Differential organ infection studies, potyvirus elimination and field performance of virus-free garlic plants produce by tissue culture / $\quad$ R. Ramirez-Malagon, L. Perez-Moreno, A. Borodanenko [and use] // Plant Cell Tiss Organ Cult. - 2006. - Vol. 86. - P. 103-110.

11. Skoog $F$. Chemical regulation of growth and organ formation in plant tissues cultured in vitro / $\mathrm{F}$. Skoog, C. O. Miler // In The Biological Action of Growth Substances : symposia of Societi for Experimental Biologi. - Cambridge : Cambridge University Press, 1957. - N. 11. - P. 118-153.

12. Biotehnologicheskie metody poluchenija i ocenki ozdorovlennogo kartofelja : metodicheskie rekomendacii ; podgot. : L. N. Trofimec, V. B. Bojko, T. V. Zejruk [i dr.]. - M., 1988. - 37 s. s.

13. Metodichnl rekomendatsiyi schodo provedennya doslidzhen $\mathrm{z}$ kartopleyu ; pldgot. : V. S. Kutsenko, A. A. Osipchuk, A. A. Podgaetskiy [ta in.] / in-t kartoplyarstva. - Nemishaeve, 2002. - $183 \mathrm{~s}$.

14. Ozdorovlennya kartopli $v$ kulturi in vitro: naukovo-metodichni rekomendatsiyi; pldgot.: R. A. Vozhegova, Yu. O. Lavrinenko, G. S Balashova [ta in.] / in-t zrosh. zemlerob. - Herson, 2013. - 20 s.

15. Optimizacija priemov ozdorovlenija, razmnozhenija i zashhity semennogo kartofelja ot virusnoj infekcii: metod. ukazanija / BelNIIZR. - Minsk, 1996. - $16 \mathrm{~s}$.

16. Biotehnologicheskie metody poluchenija i ocenki ozdorovlennogo kartofelja : metodicheskie rekomendacii; podgot.: L. N. Trofimec, V. B. Bojko, T. V. Zejruk [i dr.]. - M., 1988. - 37 s.

17. Metodika polovih i laboratornih doslidzhen na zroshuvanih zemlyah / [R. A. Vozhegova, Yu. O. Lavrinenko, M. P. Malyarchuk ta in.] ; za red. R. A. Vozhegovoyi / in-t zrosh. zemlerob. - Herson, 2014. $286 \mathrm{~s}$. 